\author{
Dagmara Alsztyniuk \\ Uniwersytet Mikołaja Kopernika \\ Instytut Języka Polskiego
}

\title{
Skladniowe i semantyczne cechy ciągu toto
}

Słowa klucze: syntaktyka, semantyka, rzeczownik, reduplikacja

Celem artykułu jest opis właściwości składniowych i semantycznych cią$\mathrm{gu}^{1}$ toto. Jest to jeden z występujących we współczesnej polszczyźnie ciągów złożonych z dwóch identycznych elementów, powstałych najprawdopodobniej w wyniku reduplikacji pojedynczego elementu. Proces reduplikacji jako taki występuje na wszystkich płaszczyznach języka², stąd też podstawową kwestią przy badaniu tego typu ciągów jest ustalenie, czy są one produktem procesu powtarzania dotyczącego całej klasy jednostek, czy też same konstytuują odrębne jednostki języka ${ }^{3}$ (gdzie powtórzeniu formy nie towarzyszy analogiczne powtórzenie treści).

Ze względu na swoją postać graficzną toto może budzić pewne wątpliwości jako wyrażenie powstałe w wyniku powtórzenia pojedynczego elementu (większość analogicznych ciągów składa się z dwóch odrębnych segmentów

${ }^{1}$ Przez ciag w tym artykule rozumiem sekwencję następujących po sobie znaków graficznych bądź fonicznych, nie przesądzając, czy sekwencja ta stanowi jednostkę języka.

2 Szerzej o różnych aspektach reduplikacji por. Daszczyńska 1997, Dobaczewski 2006, Walusiak 1999, Wierzbicka 1999.

3 Termin jednostka języka przyjmuję za A. Bogusławskim (por. Bogusławski 1976, 1988) i na potrzeby artykułu będę go stosować zmiennie z terminem jednostka leksykalna. 
graficznych, np. ledwo ledwo, tuż tuż). Ciągłość zapisu mogłaby sugerować, iż jest to całość złożona $\mathrm{z}$ dwóch takich samych sylab, jak np. mama czy tata, jednakże zapis taki wydaje się kwestią konwencjonalną (powodowaną być może koniecznością oddania różnic prozodycznych między interesującym mnie ciągiem toto a innymi konstrukcjami z występującymi w sąsiedztwie dwiema jednostkami to, np. To to nie jest nawet pies., Takie proste to to nie jest., Aha, czyli to to ich ruszyto.), nietrudno zauważyć wyraźną zależność między to i toto (o zupełnie innym charakterze niż zależność między ta i tata, o ile w ogóle o jakiejś zależności innej niż czysto graficzne podobieństwo można tu mówić).

Żaden z przebadanych słowników polszczyzny ogólnej nie wskazuje na jakikolwiek związek toto i to, ale generalnie podają one niewiele informacji na temat toto. Stosunkowo najwięcej jest ich w ISJP: „W potocznej polszczyźnie słowa toto używamy zamiast innych zaimków rzeczownych, wskazując nim rzeczy lub osoby. Słowo używane z lekceważeniem lub żartobliwie”. Definicje w pozostałych dwóch słownikach są do siebie bardzo podobne - USJP: „potoczne, lekceważące lub żartobliwe, o kimś lub o czymś, najczęściej mało ważnym”; SJPDor: „pogardliwie lub żartobliwie o kimś lub o czymś”. Pomimo że słowniki notują toto jako odrębne hasło (jednosegmentowe), fakt, że toto można swobodnie zamieniać na to w większości kontekstów, nakazuje rozważenie, czy nie chodzi o powtarzanie to (a wtedy toto byłoby specyficznym połączeniem dwóch odrębnych jednostek zapisywanych łącznie), por.:

(1) Głupie toto, ale ma smykałkę do maszyn.

(2) Głupie to, ale ma smykałkę do maszyn.

(3) A toto żółte, to jeździ?

(4) A to żółte, to jeździ?

Dalsza analiza kontekstów, w których występuje badany ciąg, pokazuje, że substytucja nie jest jednak tak swobodna, por.:

(5) Teraz widzę toto wyraźnie.

(6) Teraz widzę to wyraźnie.

(7) Ależ toto jest głupie!

(8) Ależ to jest głupie!

Zdania (6) i (8) są zupełnie poprawne, jednak pojawiające się w nich to nie ma tak ścisłego odniesienia do obiektów materialnych jak toto. Oczywi- 
ście zdania te mogą mieć takie samo znaczenie jak zdania (5) i (7), jednak intuicyjnie raczej będą rozumiane jako traktujące o kwestiach abstrakcyjnych (gdzie to = to działanie, ta kwestia, ten problem itp.).

Pomijając chwilowo kwestię ograniczonego odniesienia toto, należy zwrócić uwagę na kwestię fleksji, zdecydowanie odróżniającej to i badany ciąg ${ }^{4}$. To rzeczownikowe posiada pełny paradygmat form przypadkowych:

(9) Popatrzcie tylko, jak to się wije.

(10) Nie zobaczysz tego nigdzie indziej.

(11) Przyglądał się temu z zachwytem.

(12) Podpalało się to, ogień syczał i leciało.

(13) Trzeba z tym iść do lekarza.

(14) Porozmawiamy o tym później.

Umieszczenie toto $\mathrm{w}$ analogicznych kontekstach (wymagających form przypadków zależnych) pokazuje drastyczne ograniczenia paradygmatu tego ciągu, por.:

(15) Popatrzcie tylko jak toto się wije.

(16) *Nie zobaczysz toto/totego nigdzie indziej.

(17) *Przyglądał się toto/totemu z zachwytem.

(18) Podpalało się toto, ogień syczał i leciało.

(19) *Trzeba z toto/totym iść do lekarza.

(20) *Porozmawiamy o toto/totym później.

Wyraźna różnica fleksyjna pomiędzy toto a to (żaden z leksemów o postaci TO nie ma takich właściwości fleksyjnych) pozwala uznać toto za odrębne zjawisko i traktować je jako jednostkę leksykalną.

Interesującą kwestią jest kwalifikacja gramatyczna toto. Według tradycyjnych gramatyk badaną jednostkę należałoby zaliczyć do klasy zaimków (wyróżnianej na podstawie kryteriów znaczeniowych; ich cechą konstytutywną miałaby być deiktyczność, por. Bańko 2005: 71-86). Ze względu na to, jaką część mowy zastępuje, należałoby stwierdzić, że toto to zaimek rzeczowny (choć zawarta w definicji w ISJP sugestia: „używany zamiast in-

4 Ze względu na kontekst gramatyczny toto jest „najbliżej” to rzeczownikowego, jednak różnice fleksyjne, o których mowa, odróżniają toto od jakiegokolwiek to; więcej na temat różnych leksemów TO, por. Wiśniewski 1987, 1990. 
nych zaimków rzeczownych", kazałaby zastanowić się nad istnieniem jakiejś podklasy zaimków „zaimnych”). Z powodu „,niegramatyczności” kryterium, na podstawie którego wyróżniana jest klasa zaimków, trudno uznać je za jednoznaczne. Ponieważ toto zajmuje w wypowiedzeniu pozycję typową dla rzeczownika, należy rozważyć możliwość zaliczenia badanego ciągu do tej właśnie klasy. Rzeczowniki posiadają kategorię selektywną rodzaju oraz kategorię fleksyjna przypadka i liczby. Jedynym kryterium niepozostawiającym wątpliwości w stosunku do toto jest nieodmienność przez rodzaj, por.:

(21) Przyszło toto i zaczęło się głupio śmiać.

(22) *Przyszedł toto i zaczął się głupio śmiać.

(23) *Przyszła toto i zaczęła się głupio śmiać5.

Próbę odmiany toto przez przypadki pokazują zdania (15)-(20), podobna próba w stosunku do kategorii liczby też wskazuje na ograniczenia, por.:

(24) *Nawet butów nie potrafią sobie toto zasznurować.

(25) *Przyszły toto całe umorusane sadzą.

Jak pokazują przywołane przykłady, jedyne wartości przypadka, jakie może przybrać toto, to mianownik i biernik liczby pojedynczej. Użycie tej jednostki w kontekstach wymagających innych wartości daje konstrukcje dewiacyjne. Ponadto oba „dostępne” przypadki mają homonimiczną postać. Laskowski wyróżnia pewną podklasę rzeczowników (por. Laskowski 1998: 62), którą określa jako zaimki; rozumie je jako odpowiadające podklasie zaimków rzeczownych. Jako cechy gramatyczne tej podklasy podaje nieodmienność przez liczbę (który to warunek spełnia toto) oraz „swoistą strukturę form fleksyjnych przypadka z niepodzielną morfologicznie formą przypadkową, kumulującą funkcje wykładnika znaczenia leksykalnego i znaczenia gramatycznego (wskaźnika kategorii przypadka) lub z częściowym supletywizmem" (co trudno odnotować w stosunku do dwóch dostępnych form przypadka dla toto). Wspomniana nieodmienność przez liczbę

${ }^{5}$ Chodzi tu oczywiście o czysto gramatyczną kategorię rodzaju. Ze względu na swoje własności ścisłej referencji toto nie wnosi informacji na temat rodzaju gramatycznego jednostki, którą zastępuje, innymi słowy, może równie dobrze odnosić się do nazwy obiektu rodzaju męskiego i żeńskiego, np. Stanęła $w$ drzwiach. Chude toto i mało apetyczne. Pytasz o syna Anki? Ćpa toto, pyskuje, rapuje. 
mogłaby świadczyć o przynależności toto do wyróżnionej wyżej podklasy Laskowskiego, jednak sam autor pisze, że owa nieodmienność jest wspólna dla zaimków (w jego wąskim rozumieniu) oraz rzeczowników plurale tantum i singulare tantum, wobec czego należałoby zaklasyfikować toto do rzeczowników o „wybrakowanym” paradygmacie. O tego rodzaju rzeczownikach, tzw. rzeczownikach defektywnych, pisał Andrzej Dyszak (2001: 141-154), jednak jako defektywne analizuje on jedynie rzeczowniki plurale tantum i singulare tantum (trudno powiedzieć, co właściwie autor rozumie pod pojęciem defektywności, najprawdopodobniej uznaje on definicję defektywności Romana Laskowskiego, por.: ,taki paradygmat formalny, który nie pozwala na morfologiczne rozróżnienie wartości którejś z kategorii fleksyjnej leksemu, pozbawiony jest morfologicznie wykładników tej kategorii” (cyt. za: Dyszak 2001), która obejmuje przebadane przez niego rzeczowniki, jednak nie oddaje defektywności toto). W całej swojej pracy Dyszak jako nieodmienność traktuje pełen synkretyzm form. Jeżeli za nieodmienność uznać neutralizację pod względem przypadka, a za defektywność brak morfologicznych wykładników kategorii fleksyjnej, to trudno znaleźć termin oddający cechy toto, czyli nie tylko homonimiczną postać przypadków, ale brak jakichkolwiek form innych niż mianownik i biernik liczby pojedynczej. Właściwości toto lepiej odzwierciedla pojęcie defektywności w rozumieniu Zygmunta Saloniego i Marka Świdzińskiego (2001: 91-91). Wspomina o nim również Dyszak w swoim artykule, jednak dodaje, że kwestia defektywności jest tam omawiana dość pobieżnie. Saloni i Świdziński piszą o paradygmatach defektywnych jako o „odpowiadających leksemom nie mającym wszystkich form wyznaczonych przez pełen system opozycji dla danej klasy" i jako przykład podają m.in. słowo $d u \dot{z} o$ (homonimiczne z przysłówkiem $d u \dot{z} o$ ), które posiada jedynie homonimiczne formy mianownika, dopełniacza (tylko przyczasownikowego) i biernika. Opierając się na powyższych ustaleniach, można na obecnym etapie badań uznać toto za specyficzny rzeczownik o defektywnym paradygmacie.

Inną kwestią jest znaczenie toto. Definicje słownikowe sugerują, że ciąg ten służy mówieniu „o kimś lub o czymś”, jednak pozbawione szerszego kontekstu zdania z toto pokazują, że jednostka ta nie orzeka niczego o obiektach, do których się odnosi, nie wnosi żadnych informacji na temat ich właściwości; wymagany jest kontekst (językowy lub pozajęzykowy, np. w postaci 
odpowiedniego gestu) na tyle precyzyjny, aby odbiorca mógł zidentyfikować obiekt, o którym nadawca mówi toto, por.:

(26) I wtedy podjechał ten samochód. Małe toto, pokraczne, cud, że jeździ.

(27) Nie wiesz, które to? Toto, co tam stoi na półce, na prawo od lampy.

(28) Szczeka toto, warczy, a dopiero co stanęło na łapach.

Ważne jest, że nazwy, które może zastępować toto, muszą odnosić się do obiektów materialnych, ludzi, zwierząt, rzeczy (co pokazało już porównanie toto i to), por.:

(29) *Zostało toto poruszone na ostatnim zebraniu.

(30) *Załatw toto przy najbliższej okazji ${ }^{6}$.

Użycie toto zamiast właściwej nazwy obiektu, o którym mowa (przy jednoczesnym niewnoszeniu informacji na jego temat), pokazuje, iż zasadniczą funkcją tej jednostki jest wyrażanie stosunku nadawcy do danego obiektu. Wszystkie przebadane słowniki sugerują, że ,wartością”, jaką niesie ze sobą toto, jest lekceważenie (oczywiście słowniki przedstawiają nieco większą gamę kwalifikatorów pragmatycznych - pojawia się również pogardliwie i żartobliwie, jednak na potrzeby tego artykułu można uznać, nie wchodząc w różnicę między pogardliwym a lekceważacym, że wszystkie te określenia opierają się na pewnym „odebraniu ważności” obiektowi, o którym się mówi, za wyraz czego uznam określenie lekceważacy). Konteksty, w których występuje toto, również potwierdzają te sugestie. Dodatkowe określenia dotyczące obiektów oznaczanych przez badaną jednostkę, pojawiające się w poświadczonych użyciach, są na ogół pejoratywne, por.:

(31) Małe toto i chuderlawe.

(32) Głupie toto, ale ma smykałkę do maszyn.

(33) Małe toto, pokraczne, cud, że jeździ.

Oczywiście można by uznać, że to właśnie pejoratywny kontekst wprowadza owo lekceważenie, jednakże umieszczenie toto w kontekście mówią-

${ }^{6}$ Oczywiście chodzi tu o intuicyjnie rozumiane znaczenie tych zdań w naturalnym dla nich kontekście (można by uznać, że byłyby one poprawne w jakiejś specyficznej sytuacji komunikacyjnej, gdyby np. pierwsze odnosiło się do przesuwania mebli, a drugie było zleceniem zabójstwa). 
cym o danym obiekcie coś dobrego, wyrażającym szacunek (chodzi o użycie nienacechowane, nie wskazujące na ironię czy sarkazm), jest co najmniej nienaturalne, por.:

(34) 'Bardzo toto szanuję.

(35) 'Nie dość, że toto piękne i zdrowe, to jeszcze inteligentne.

(36) ? Olśniewająco piękne toto, nie widziałem piękniejszej kobiety!

Dodatkowym argumentem potwierdzającym lekceważący charakter toto jest fakt, że w dostępnych korpusach języka polskiego nie znalazłam żadnego „pozytywnego" kontekstu, w którym byłaby użyta badana jednostka (zdania (34)-(36) zostały spreparowane do analizy). Czysto intuicyjnie trudno przyjąć, że określenie kogoś słowem toto (którego już sam rodzaj gramatyczny niejako pozbawia płci obiekt, o którym mowa) jest zupełnie neutralne.

Wyodrębnienie powyższych cech pozwala na zaproponowanie wstępnej, szkicowej definicji toto:

(37) toto

'coś, o czym myślę, że nie jest to tak ważne, aby powiedzieć, co to jest (powiedzieć tego nazwę)

wiesz, o czym mówię'

Definicja ta jest jedynie próbą zarysowania właściwości semantycznych toto, tym bardziej że chociażby użyte w niej słowo ważny nie jest składnikiem prostym semantycznie, co powoduje konieczność dalszych badań nad precyzyjniejszą definicją tej jednostki.

\section{Wykaz skrótów}

ISJP: Inny słownik języka polskiego, 2000, red. M. Bańko, t. I-II, Warszawa: PWN. SJPDor: Słownik języka polskiego, 1958-1969, red. W. Doroszewski, t. I-XI, Warszawa: PWN.

USJP: Uniwersalny stownik języka polskiego, 2003, red. S. Dubisz, t. I-III, Warszawa: PWN. 


\section{Bibliografia}

BAŃKo M., 2005, Wyktady z polskiej fleksji, Warszawa: PWN.

BogusŁawski A., 1976, O zasadach rejestracji jednostek języka, Poradnik Językowy, nr 8, s. 356-364.

BogusŁawski A., 1988, Preliminaria gramatyki operacyjnej, tłum. R. Gozdawa-Gołębiowski, Polonica XIII, s. 163-223.

DasZCZyŃska I., 1997, Reduplikacja jako jeden ze sposobów pierwotnej derywacji frazeologicznej, w: M. Blicharski, H. Fontański (red.), Wspótczesne tendencje języków stowiańskich, t. 2, Katowice: Wydawnictwo UŚ, s. 54-62.

Dobaczewski A., 2006, O pewnych konstrukcjach opartych na reiteracji, Polonica $X X V I-X X V I I$, s. $161-169$.

DysZAK A., 2001, Rzeczowniki i czasowniki defektywne w systemie fleksyjnym współczesnej polszczyzny, Biuletyn PTJ LVII, s. 141-154.

Laskowski R., 1998, Podstawowe pojęcia morfologii, w: R. Grzegorczykowa, R. Laskowski, H. Wróbel, Gramatyka wspótczesnego języka polskiego. Morfologia, Warszawa: PWN, s. 27-86.

SAloni Z., ŚwidziŃSKi M., 2001, Składnia współczesnego języka polskiego, Warszawa: PWN.

Walusiak E., 1999, On some aspects of reiteration in the text, w: K. Böttger, M. Giger, B. Wiemer (red.), Beitrage der Europäischer Slavistischen Linguistik (POLYSLAV), Band 2, München: Otto Sagner, s. 295-299.

Wierzbicka A., 1999, Włoska reduplikacja. Pragmatyka międzykulturowa i semantyka illokucyjna, tłum. A. Kochańska, w: J. Bartmiński (red.), Język - umyst - kultura, Warszawa: PWN, s. 270-299.

Wiśniewski M., 1987, Formalnogramatyczny opis leksemów TO. 1. Słowo to w funkcji rzeczownika lub przymiotnika, Acta Universitatis Nicolai Copernici. Filologia polska XXIX, s. 27-42.

Wiśniewski M., 1990, Formalnogramatyczny opis leksemów TO. 2. Słowo to w funkcji spójnika, partykuły lub czasownika niewłaściwego, Acta Universitatis Nicolai Copernici. Filologia polska XXXI, s. 91-119. 


\section{Syntactic and semantic features of the Polish expression toto ( s u m mary)}

The article deals with the syntactic and semantics features of the Polish reduplicative expression toto. This lexical unit is composed of two identical elements and it is always uninflected. It is used instead of nouns, especially names of things and people, in order to show disregard. The article attempts to demonstrate that toto is most probably a defective noun. 